Egyptian Journal of Aquatic Biology \& Fisheries

Zoology Department, Faculty of Science,

Ain Shams University, Cairo, Egypt.

ISSN $1110-6131$

Vol. 24(5): 353 - 359 (2020)

www.ejabf.journals.ekb.eg

\title{
Effects of the marine microalga (spirulina) on protein deficiency signs in hepatocellular carcinoma-bearing mice
}

\author{
Aya M. Shehata , Asmaa A. Mahmoud*, Yomna I. Mahmoud, Nagui H. Fares \\ Zoology Department, Faculty of Science, Ain Shams University, Cairo, Egypt \\ *Corresponding Author: asmaamahmoud@sci.asu.edu.eg; \\ asmaa_ainshams@yahoo.com
}

ARTICLE INFO

Article History:

Received: July 25, 2020

Accepted: Aug. 7, 2020

Online: Aug. 11, 2020

Keywords:

Spirulina,

marine alga, protein deficiency,

hepatocellular carcinoma, mouse.

\begin{abstract}
Spirulina is an edible blue-green microalga that is rich in numerous bioactive compounds especially proteins. Protein deficiency is associated with various disease conditions in human, including cancer. The present study was carried out to evaluate the effect of the marine microalga "spirulina" on protein deficiency signs in hepatocellular carcinoma-bearing mice. Hepatocarcinoma was induced by a single injection of diethylnitrosamine $(100 \mathrm{mg} / \mathrm{kg}$, intraperitoneally) followed by 22 weekly injections of carbon-tetrachloride $(0.5 \mathrm{mg} / \mathrm{kg}$, i.p). Spirulina (250 and $500 \mathrm{mg} / \mathrm{kg}$ bw) was given orally, from week 25 to 28 , after the establishment of hepatocellular carcinoma. The results showed that HCCbearing animals several clinical signs of protein deficiency including weakness and skeletal muscle loss, decreased body weight, hair thinnening and loss, in addition to abdominal edema. On the other hand, spirulinatreated animals recovered the signs of HCC-associated protein deficiency. In conclusion, spirulina proved to be an adequate protein source to ameliorate the protein deficiency-related alterations in HCC-bearing animals.
\end{abstract}

\section{INTRODUCTION}

Marine microorganisms are sources of a massive amount of bioactive compounds with remarkable pharmaceutical activities. Among these marine microorganisms is spirulina, an edible blue-green microalga that is known to be rich in numerous bioactive compounds (Akbarizare et al., 2020). Spirulina is multicellular, filamentous and spiral blue-green alga that grows in alkaline water, harvested and processed easily and has very high macro- and micro-nutrient contents. It has long been used as a dietary supplement by people living close to the alkaline lakes, where it is naturally found (Habib et al., 2008). Despite the fact that spirulina was an essential component of ancient diets (Farrar, 1966; Bjørkelo, 1976; Ciferri, 1983), its popularity has emerged again relatively recently 
because of its nutritional value and relative safety (Smiezeck et al., 2017), and its digestability as it lacks hard cellulose that is present in other plants (Moorhead et al., 2011).

Spirulina contains approximately $70 \%$ easily digestible protein where 18 of 22 amino acids and all of the essential amino acid are available, making it a unique vegetarian source of complete protein (Dillon et al., 1995). This nutritious food is an excellent source of B vitamins, and contains vitamin E, a highly bioavailable source of iron, 14 naturally chelated minerals and numerous trace elements (Dillon et al., 1995; Somchit et al., 2007). Due to its nutritional value, spirulina has been used in diets of aquatic organisms as a possible replacement of fishmeal, and as a functional feed to improve the growth parameters and general health of fish in the area of aquaculture (Rosas et al., 2018). Spirulina is also used in treating Protein Energy Malnutrition (PEM) and skeletal muscle wasting associated with various disease conditions in human, including cancer (Siva Kiran et al., 2015). Treating PEM with good nutrition ameliorates many cancerassociated clinical signs and increases the survival rate of these patients (Nixon et al., 1980; Siva Kiran et al., 2015). Thus, the current study was designed to detect the potential ameliorative effects of spirulina on the body weight and protein-deficiency signs in hepatocellular carcinoma-bearing mice.

\section{MATERIALS AND METHODS}

Drugs and chemicals Diethylnitrosamine (DEN) was purchased from Sigma-Aldrich (0.95 g/ml; Sigma N0258-1G; St. Louis, MO, USA). Carbon tetrachloride was obtained from Research Lab (Cairo, Egypt). Spirulina, was obtained in commercial form as fine dark blue-green dried powder from Imtenan Healthy Shop (Obour City, Cairo, Egypt). All other chemicals were obtained from El-Nasr pharmaceutical chemicals co. (Cairo, Egypt).

Experimental animals Eighty healthy male albino mice (Mus musculus), eight-weekold, weighing 23-28g, were obtained from the Biological Unit of Theodore Bilharz Institute (Giza, Egypt). Mice were acclimatized to laboratory conditions for a week before starting the experiments. A temperature of $25^{\circ} \mathrm{C}$ and $12 \mathrm{~h}$ light/dark cycle were maintained. The animals had free access to water and standard chow pellets. The experimental protocol was approved by the Research Committee of Zoology Department, Faculty of Science, Ain Shams University.

Induction of hepatocellular carcinoma HCC was induced as described by (Uehara $\boldsymbol{e t}$ al., 2013). Briefly, diethylnitrosamine (DEN; $100 \mathrm{mg} / \mathrm{kg}$ in $0.9 \%$ saline) was injected once intraperitoneally. Two weeks later, the animals received repeated biweekly intraperitoneal injections of carbon tertrachloride $(0.5 \mathrm{ml} / \mathrm{kg}$ dissolved in corn oil $)$ up to 22 weeks. 
Experimental design The animals were randomly assigned to five groups, as follows: Group $1(\mathrm{n}=10)$ : received the vehicle and served as negative control group; Group 2 $(\mathrm{n}=10)$ : received Spirulina $(500 \mathrm{mg} / \mathrm{kg} \mathrm{bw})$ for 4 weeks by a gastric gavage, and served as Spirulina-control group; Group $3(\mathrm{n}=20)$ : HCC-control group. Group 4 and $5(\mathrm{n}=20)$ : were treated with Spirulina (at dose of 250 and $500 \mathrm{mg} / \mathrm{kg} \mathrm{b} . \mathrm{w}$, respectively) for 4 weeks, starting from week 25 until week 28 of HCC induction. At the end of the experiment, all mice were examined for clinical signs of protein deficiency such as weakness and muscle wasting, and body weight decrease, fur changes, and abdominal edema.

Statistical analysis Numerical data were expressed as mean values and standard error of means. GraphPad Prism (version 5.0, GraphPad software, San Diego, CA, USA) was used to conduct all statistical analysis. Data were analysed statistically using One-way ANOVA followed by post hoc multiple comparisons (Tukey's test) for comparative analysis between the groups. $P<0 \cdot 05$ was regarded as statistically significant.

\section{RESULTS}

At the end of the experiment, non-treated (negative control) mice appeared healthy and active, with white and soft fur (Figure 1a) and significant increase in body weight (Table1). When treating normal mice with spirulina, the animals showed no significant changes in their appearance or their behavior; however, they had slightly insignificant decreased body weight compared with that of the blank control group (Table 1). On the other hand, HCC-bearing animals became hypoactive and lethargic, and suffering from abdominal edema (Figure 1c). Their fur was light, matted, and slightly yellowish (Figure 1b). The final weights of HCC animals were significantly lower compared with the average weight gain of the negative control group as shown in Table 1. Treating HCC animals with spirulina resulted in recovery from the clinical symptoms of HCC. Although spirulina-treated HCC animals showed signficant decreased body weight compared with HCC control ones; however, the mice were relatively active, with soft white fur and no abdominal edema (Figs. 1d,e; table 1).
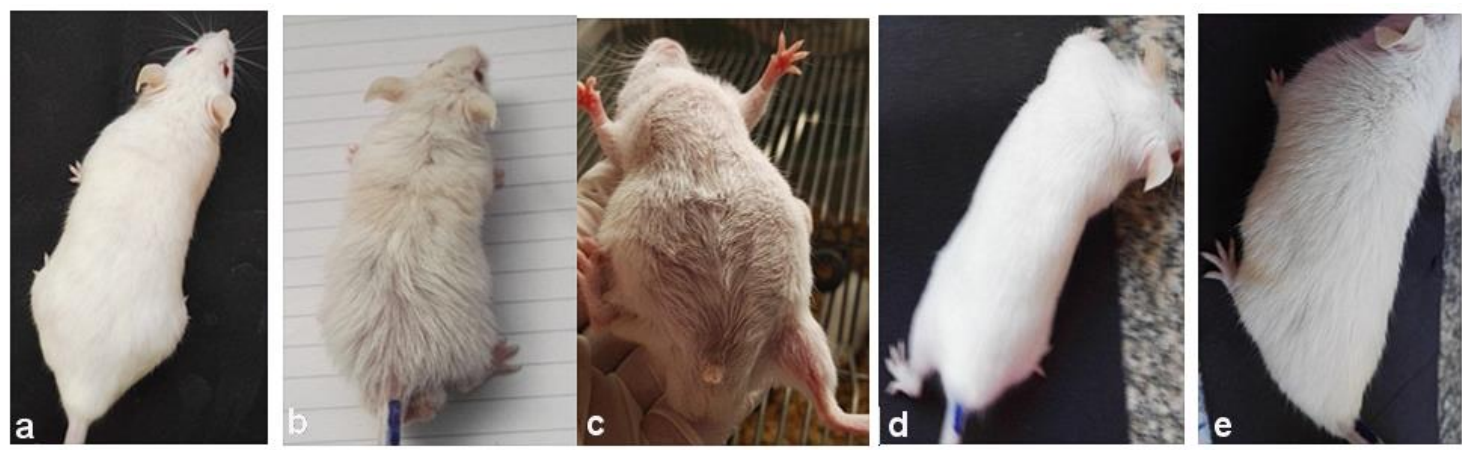

Figure 1: Effect of spirulina on hepatocellular carcinoma-bearing mice 
Table 1: Effect of spirulina on body weight in hepatocellular carcinoma-bearing mice

\begin{tabular}{|c|c|c|c|c|c|c|c|c|c|c|}
\hline \multirow{4}{*}{$\begin{array}{c}\text { Parameter } \\
\begin{array}{c}\text { Average body } \\
\text { weights }\end{array}\end{array}$} & \multirow{2}{*}{\multicolumn{2}{|c|}{ Normal }} & \multirow{2}{*}{\multicolumn{2}{|c|}{$\begin{array}{c}\text { Spirulina } \\
\text { Control }\end{array}$}} & \multicolumn{6}{|c|}{ HCC mice } \\
\hline & & & & & \multicolumn{2}{|c|}{ Control } & \multicolumn{2}{|c|}{$\begin{array}{l}\text { Spirulina } \\
250 \mathrm{mg} / \mathrm{kg}\end{array}$} & \multicolumn{2}{|c|}{$\begin{array}{c}\text { Spirulina } \\
500 \mathrm{mg} / \mathrm{kg}\end{array}$} \\
\hline & Initial & Final & Initial & Final & Initial & Final & Initial & Final & Initial & Final \\
\hline & 22.06 & 43.69 & 22.23 & 38.87 & 21.34 & 38.56 & 22.95 & 36.86 & 23.17 & 40.76 \\
\hline $\begin{array}{l}\% \text { b. wt } \\
\text { change }\end{array}$ & \multicolumn{2}{|c|}{99.10} & \multicolumn{2}{|c|}{76.41} & \multicolumn{2}{|c|}{$72.90^{\mathrm{a}}$} & \multicolumn{2}{|c|}{$54.14^{\mathrm{b}}$} & \multicolumn{2}{|c|}{$49.71^{b}$} \\
\hline
\end{tabular}

Values are expressed as means \pm SEM.

${ }^{a}$ indicates the significant difference of HCC control group vs. the corresponding normal group at $\mathrm{P}<0.05$.

${ }^{\mathbf{b}}$ indicates the significant difference of spirulina-treated groups $v s$. HCC control group at $\mathrm{P}<0.05$.

\section{DISCUSSION}

The present study was carried out to evaluate the effect of spirulina on clinical signs of protein deficiency in murine hepatocellular carcinoma. At the end of the current study (week 28 after HCC induction), several signs of protein deficiency appeared in surviving HCC-bearing mice. The first sign of protein deficiency in HCC animals was the weakness and loss of skeletal muscles- the body's largest reservoir of protein. Luo et al. (2013) also observed that HCC mice became lethargic and lean, 20 weeks after the initiation of HCC induction. The same group of animals also showed significantly decreased body weight compared with that of the negative control group, as reported earlier by Abdo et al. (2015), Kumar et al. (2016), Wang et al. (2016), Fathy et al. (2017), and Ding et al. (2019). This decrease in body weight gain was associated with abdominal edema, another sign of protein deficiency. One of protein's main functions is to maintain oncotic pressure that draws fluid into the blood circulation and prevents excessive amounts of fluid from accumulating in tissues. Severe protein deficiency leads to lower oncotic pressure, resulting in fluid accumulation in the tissues and abdominal cavity (Singh and Seth, 2017).

Furthermore, HCC-bearing animals in the current study suffered from many fur changes including hair thining, dryness and loss. Luo et al. (2013) and Wang et al. (2016) also mentioned that the fur of HCC mice was matted and lusterless, and turned from white, soft, and fine to yellow, hard, and crude. Since protein is the main structural component of hair, so, protein malnutrition can result in hair thining and loss (McLaren, 1987; Guo and Katta, 2017).

Spirulina-treated animals showed signs of recovery from the weakness, fur lightness and loss, and abdominal edema that result from severe protein deficiency. These observations could be explained in the light of the high protein content of spirulina (Dillon et al., 1995). In conclusion, spirulina proved to be an adequate protein source to ameliorate the protein deficiency-related alterations in HCC-bearing animals. 


\section{Competing interests}

We declare that we have no conflict of interest. This research did not receive any specific grant from funding agencies in the public, commercial, or not-for-profit sectors.

Funding This research did not receive any specific grant from funding agencies in the public, commercial, or not-for-profit sectors.

\section{REFERENCES}

Abdo, W.; Hirata, A.; Shukry, M.; Kamal, T.; Abdel-Sattar, E.; Mahrous, E. and Yanai, T. (2015). Calligonum comosum extract inhibits diethylnitrosamine-induced hepatocarcinogenesis in rats. Oncol. Let., 10:716-722.

Akbarizare, M.; Ofoghi, H.; Hadizadeh, M. and Moazami, N. (2020). In vitro assessment of the cytotoxic effects of secondary metabolites from Spirulina platensis on hepatocellular carcinoma. Egypt. Liv. J., 10:1-8.

Bjørkelo, AJ. (1976). State and Society in Three Central Sudanic Kingdoms: KanemBornu, Bagirmi, and Wadai. MA thesis, University of Bergen, Bergen, Norway.

Ciferri, O. (1983). Spirulina, the edible microorganism. Microbiol. Rev., 47: 551.

Dillon, J.C.; Phuc, A.P. and Dubacq, J.P. (1995). Nutritional value of the alga Spirulina. In Plants in human nutrition. Karger Publishers. Vol. 77, pp. 32-46

Ding, Y.; Peng, Z.; Ding, L. and Peng, Y. (2019). Baishouwu extract suppresses the development of hepatocellular carcinoma via TLR4/MyD88/NF- $\kappa \mathrm{B}$ pathway. Front. Pharmacol., 10:389.

Farrar, W.V. (1966). Tecuitlatl; a glimpse of Aztec food technology. Nature, 211: 341342.

Fathy, A.H.; Bashandy, M.A.; Bashandy, S.A.; Mansour, A.M. and Elsadek, B. (2017). Sequential analysis and staging of a diethylnitrosamine-induced hepatocellular carcinoma in male Wistar albino rat model. Canad. J. physiol. Pharmacol., 95:1462-1472.

Guo, E.L. and Katta, R. (2017). Diet and hair loss: effects of nutrient deficiency and supplement use. Dermatol. Pract. Concept., 7:1.

Habib, M.A.B.; Parvin, M.; Huntington, T.C. and Hasan, M.R. (2008). A review on culture, production and use of spirulina as food for humans and feeds for domestic animals and fish. FAO Fisheries and Aquaculture Circular. Rome, FAO., 1034: 1-25

Kumar, R.S.; Kumar, S.V.; Balasubramanian Rajkapoor, N.P. and Mahendiran, D. (2016). Chemopreventive effect of Indigofera linnaei extract against diethylnitrosamine induced hepatocarcinogenesis in rats. J. App. Pharmaceut. Sci., 6: 199-209.

Luo, M.; Yang, F.; Huang, S. X.; Kuang, Z. P.; Luo, X. L.; Li, Y. D.; and Xie, Y. A. (2013). Two-stage model of chemically induced hepatocellular carcinoma in mouse. Oncol. Res., 20: 517-528. 
McLaren, D.S. (1987). Skin in protein energy malnutrition. Arch. Dermatol., 123: 16741676.

Moorhead, k.; Capelli, B. and Gerald, R. (2011). Spirulina Nature's Superfood. Third edition. Cyanotech Corporation, Kailua-Kona, Hawaii.

Nixon, D.W.; Heymsfield, S.B.; Cohen, A.E.; Kutner, M.H.; Ansley, J.; Lawson, D.H. and Rudman, D. (1980). Protein-calorie undernutrition in hospitalized cancer patients. Am. j. med., 68: 683-690.

Rosas, V.T.; Poersch, L.H.; Romano, L.A. and Tesser, M.B. (2019). Feasibility of the use of Spirulina in aquaculture diets. Rev. Aqua.,11:1367-1378.

Singh, P. and Seth, A. (2017). From Kwashiorkor to Edematous Malnutrition. India Pediator., 54:763-764.

Siva Kiran, R.R.; Madhu, G.M. and Satyanarayana, S.V. (2015). Spirulina in combating Protein Energy Malnutrition (PEM) and Protein Energy Wasting (PEW)A review. J. Nutr. Res., 1: 62-79.

Śmieszek, A.; Giezek, E.; Chrapiec, M.; Murat, M.; Mucha, A.; Michalak, I. and Marycz, K. (2017). The influence of Spirulina platensis filtrates on Caco-2 proliferative activity and expression of apoptosis-related microRNAs and mRNA. Mar. drugs, 15: 65.

Somchit, M.N.; Rahmah, S.S.; Zuraini, A.; Bustamam, A.A.; Zakaria, Z.A.; Somchit, N. and Shamsuddin, L. (2007). Gastroprotective activity of Spirulina platensis in acetic acid and ethanol induced ulcers in rats. J. Nat. Rem., 7:37-42.

Uehara, T.; Pogribny, I.P. and Rusyn, I. (2014). The DEN and CCl4- induced mouse model of fibrosis and inflammation- associated hepatocellular carcinoma. Curr Protoc Pharmacol., 66:14-30.

Wang, H.; Xu, H.; Qu, L.; Wang, X.; Wu, R.; Gao, X.; Jin, Q. and Niu, J. (2016). Red blood cell distribution width and globulin, noninvasive indicators of fibrosis and inflammation in chronic hepatitis patients. Eur. J. Gastroenterol. Hepatol., 28:9971002. 


\section{ARABIC SUMMARY}

تأثير الطحالب البحرية الدقيقة (Spirulina) على علامات نقص البروتين في الفئران المصابة بسرطان الكبا

آية منصور شحاتة, أسماء أحمد محمود, يمنى إبراهيم محمود, ناجى حسن فارس

قسم علم الحيوان, كلية العلوم, جامعة عين شمس, القاهرة, جمهورية مصر العربية

تعتبر Spirulina من الطحالب الاقيقة الخضراء الصالحة للأكل والغنية بالعديد من المركبات

النشطة بيولوجيا وخاصة البروتينات. يرتبط نقص البروتين بالعديد من الحالات المرضية في الإنسان، بما

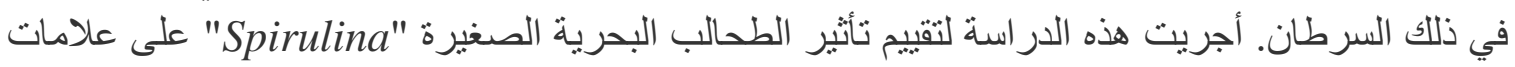
نقص البروتين في الفئران المصابة بسرطان الكبد. تم إحداث سرطان الكبد عن طريق حقن ثنائي إيثيل

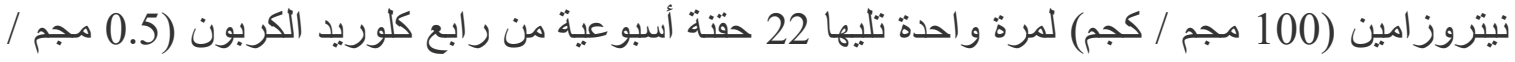

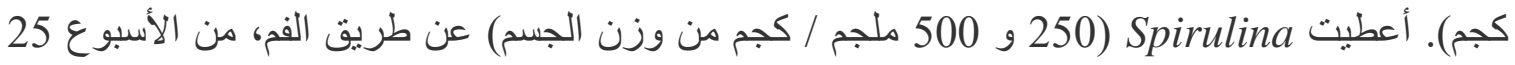

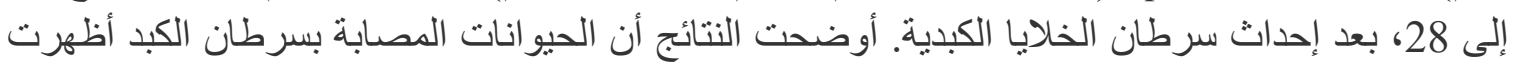

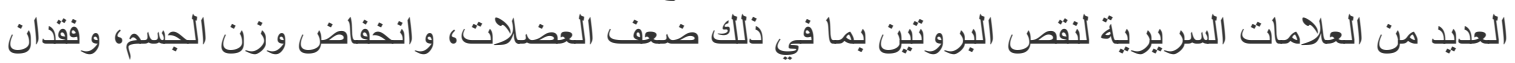

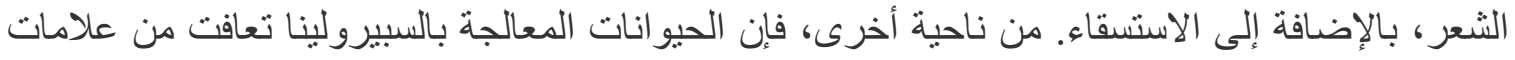

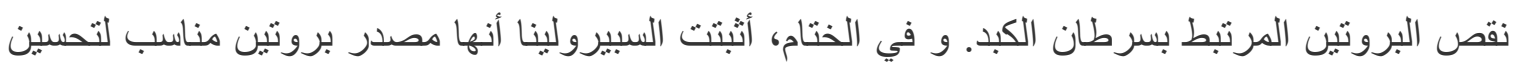
التغييرات المتعلقة بنقص البروتين في الحبو انات المصابة بسرطبن فئن الكبد. 